\author{
JOSÉ JUAN MORESO, CHIARA VALENTINIC
}

\title{
IN THE REGION OF MIDDLE AXIOMS: JUDICIAL DIALOGUE AS WIDE REFLECTIVE EQUILIBRIUM AND MID-LEVEL PRIN- CIPLES
}

\author{
(Accepted 29 March 2021)
}

\begin{abstract}
This article addresses the use of foreign law in constitutional adjudication. We draw on the ideas of wide reflective equilibrium and public reason in order to defend an engagement model of comparative adjudication. According to this model, the judicial use of foreign law is justified if it proceeds by testing and mutually adjusting the principles and rulings of our constitutional doctrines against reasonable alternatives, as represented by the principles and rulings of other reasonable doctrines. By this, a court points to a wide reflective equilibrium, justifying its own interpretations with reasonable arguments, i.e. arguments that are acceptable from the perspectives defined by other constitutional doctrines, as endorsed by other courts. The point of a judicial engagement of this sort is to work out an overlap between different, reasonable, doctrines in the judicial forum, as part of a liberal forum of public reason. Here, the exercise of public reason filters out the premises of comprehensive doctrines so as to leave us in the region of an overlapping consensus: a region of mid-level principles that can be shared, notwithstanding the fact of legal pluralism.
\end{abstract}

[A] ladder for ascending and descending; as, for instance, descending from a completely general principle to one neither completely general nor completely particular, and from a principle neither completely general nor completely particular to one that is completely particular. ${ }^{1}$

\footnotetext{
${ }^{1}$ Ramon Llull, Ars Brevis, in Anthony Bonner (ed. and trans.), Selected Works of Ramon Llull, (Princeton, NJ: Princeton University Press, 1985), II.1.
} 


\section{THE USE OF FOREIGN LAW IN CONSTITUTIONAL ADJUDICATION}

This article addresses the role that foreign law (and the decisions of foreign constitutional and supreme courts) should play in the reasoning of judges when interpreting constitutional norms in their own jurisdiction. In other words, our focus is on judicial cross-fertilization and the migration of constitutional ideas from one jurisdiction to another. $^{2}$

Especially in private law, courts are often called to apply norms of foreign legal systems, and they are called to do so by the norms - the rules of conflict - of their own legal systems. However, it is much more controversial whether supreme courts may opt to rely on foreign law in order to interpret and apply their own constitutions, in their own legal systems. ${ }^{3}$ This use of foreign law involves an increasing number of supreme courts, reflecting 'something deeper: a change in what counts as a legal argument. And what counts as a legal argument - as opposed to a moral, religious, economic, or political one - is the principal component in determining just what law is. ${ }^{4}$

\footnotetext{
${ }^{2}$ For an overview, see inter alia Sujit Choudhry, 'Globalization in Search of Justification: Toward a Theory of Comparative Constitutional Interpretation', Indiana Law Journal 74(3) (1999): pp. 819-892; Vlad Perju, 'Constitutional Transplants, Borrowing, and Migrations', in Michel Rosenfeld and András Sajó (eds.), The Oxford Handbook of Comparative Constitutional Law (Oxford: Oxford University Press, 2012), pp. 1304-1327; Gábor Halmai, 'The Use of Foreign Law in Constitutional Interpretation', in Michel Rosenfeld and András Sajó (eds.), The Oxford Handbook of Comparative Constitutional Law (Oxford: Oxford University Press, 2012), pp. 1328-1348; Damiano Canale, 'Comparative Reasoning in Legal Adjudication', Canadian Journal of Law and Jurisprudence 28(1) (2015): pp. 5-27.

${ }^{3}$ We refer here to constitutional democratic systems, with written and rigid constitutions - or, at least, with a bill of rights providing standards for the legitimacy of ordinary laws - and with a system of judicial review, either strong or weak. For a characterization of constitutionalism along these lines, see Joseph Raz, 'On the Authority and Interpretation of Constitutions: Some Preliminaries', in Larry Alexander (ed.), Constitutionalism. Philosophical Foundations (Cambridge: Cambridge University Press, 1998), pp. 152-193. The most powerful defence of the strong version has been provided by Ronald Dworkin. See Ronald Dworkin 'Hard Cases', in his Taking Rights Seriously (London: Duckworth, 1977), pp. 81-130; and 'Does Britain Need a Bill of Rights?', in his Freedom's Law: The Moral Reading of the American Constitution (Oxford: Oxford University Press, 1996), pp. 352-372), On the other hand, the weak version has been defended, inter alia, by Jeremy Waldron, 'The Core of the Case Against Judicial Review', Yale Law Journal 115(6) (2006): pp. 1346-1406; Mark Tushnet, Weak Courts, Strong Rights: Judicial Review and Social Welfare Rights in Comparative Constitutional Law (Princeton, NJ: Princeton University Press, 2009); Stephen Gardbaum, The New Commonwealth Model of Constitutionalism: Theory and Practice (Cambridge: Cambridge University Press, 2013); and Juan Carlos Bayón, 'Democracia y derechos: problemas de fundamentación del constitucionalismo’, in Jerónimo Betegón Carrillo et al. (eds.), Constitución y derechos fundamentales (Madrid: Centro de Estudios Políticos y Constitucionales, 2004), pp. 67-118.

${ }^{4}$ Frederick Schauer, 'Authority and Authorities', Virginia Law Review 94(8) (2008): pp. 1931-1961.
} 
In both respects - its extent and its significance for our understanding of the law - comparative constitutional adjudication is a highly contentious practice.

To start, we do not have exhaustive data about this practice. In this respect, there are two major difficulties. On the one hand, the use of foreign law by courts is often implicit and difficult to detect; on the other hand, it serves multiple aims and it may be hard to identify and classify citations of foreign law on the basis of their role in the reasoning of courts. ${ }^{5}$

Recently, however, empirical studies have made available significant data concerning the impact of comparative constitutional adjudication, which allows us to test our theoretical questions against actual judicial practice. ${ }^{6}$ Furthermore, these studies reveal that this practice is widespread across Europe and beyond, but is neither uniform nor firmly established. ${ }^{7}$

\footnotetext{
${ }^{5}$ See Ran Hirschl, 'Judicial Review and the Politics of Comparative Citations: Theory, Evidence and Methodological Challenges', in Erin F. Delaney and Rosalind Dixon (eds.), Comparative Judicial Review, (Cheltenham: Edward Elgar, 2018), pp. 403-422.

${ }^{6}$ On the lack of empirical studies and the importance of filling this gap, see the Introduction to Jakab András, Arthur Dyevre, and Giulio Itzcovich (eds.), Comparative Constitutional Reasoning (Cambridge: Cambridge University Press, 2017). This volume contributes to filling this gap by providing insights into the effective use of foreign law by courts in different jurisdictions, as do Michal Bobek, Comparative Reasoning in European Supreme Courts (Oxford: Oxford University Press, 2013); Tania Groppi and MarieClaire Ponthoreau (eds.), The Use of Foreign Precedents by Constitutional Judges (London: Bloomsbury Publishing, 2013); Martin Gelter and Mathias M. Siems, 'Networks, Dialogue or One-Way Traffic: An Empirical Analysis of Cross-Citations between Ten of Europe's Highest Courts', Utrecht Law Review 8(2) (2012): pp. 88-99; and Martin Gelter and Mathias M. Siems, 'Citations to Foreign Courts - Illegitimate and Superfluous, or Unavoidable? Evidence from Europe', American Journal of Comparative Law 62(1) (2014): pp. 35-86. As we shall mention later, these data reveal regular patterns of cross-citation, refuting, at least in factual terms, the idea that courts just cherry-pick foreign laws and precedents (see, in particular, Gelter and Siems's study of cross-citations).

${ }^{7}$ András, Dyevre, and Itzcovich, in Comparative Constitutional Reasoning, and Groppi and Ponthoreau, in The Use of Foreign Precedents by Constitutional Judges, offer insightful overviews of these aspects of the practice. See also inter alia Anthony Arnull, 'Judicial Dialogue in the European Union', in Julie Dickson and Pavlos Eleftheriadis (eds.), Philosophical Foundations of European Union Law (Oxford: Oxford University Press, 2012), pp. 109-133; Cody M. Moon, 'Comparative Constitutional Analysis: Should the United States Supreme Court Join the Dialogue?', Washington University Journal of Law \& Policy 12 (2003): pp. 229-247.
} 
We could cite a multitude of cases in which supreme courts have relied on foreign law and precedents in order to apply their own constitutions, from the Canadian Supreme Court to the South African Constitutional Court; from the Israeli Court ${ }^{8}$ to the German Constitutional Court, ${ }^{9}$ to the Spanish, Italian, Austrian Court, and so on. In many of these cases the use of foreign law has been disputed within those courts. Let us mention the debate that took place within the US Supreme Court while deciding on the case Roper $v$. Simmons, ${ }^{10}$ addressing in emblematic terms the main questions about comparative adjudication.

In Roper, the court declared the unconstitutionality of the death penalty for crimes committed under the age of $18 .{ }^{11}$ The case was decided by a divided court, with a majority of $5-4$. The majority opinion emphasized, as a crucially relevant factor for the decision, that the US was almost the only country left in the world that still permitted capital punishment for juvenile offenders:

\footnotetext{
It is proper that we acknowledge the overwhelming weight of international opinion against the juvenile death penalty, resting in large part on the understanding that the instability and emotional imbalance of young people may often be a factor in the crime [...] The opinion of the world community, while not controlling our outcome, does provide respected and significant confirmation for our own conclusions.

Over time, from one generation to the next, the Constitution has come to earn the high respect and even, as Madison dared to hope, the veneration of the American people. The document sets forth, and rests upon, innovative principles original to the American experience, such as fed-
}

\footnotetext{
${ }^{8}$ In the case Adalah v. Minister of Interior (HCJ 7052/03), concerning the legitimacy of laws restricting citizens of the West Bank and Gaza from relocating in Israeli territory. The court's decision cited precedents from several foreign courts - of the United States, Australia, Canada, England, Ireland, and South Africa - and the European Court of Human Rights. The minority opinion of Justice Barak also included a review of foreign laws, along with references to EU and international law. Both sides thus relied on foreign law and non-binding international law, albeit to reach opposite conclusions: the majority argued that the regulation under review did not violate Israeli Basic Law, whereas Justice Barak's opinion found it unconstitutional. But the two opinions argued for different uses of foreign law. The majority rejected Justice Barak's 'analogical' approach to comparative adjudication, and, while conceding the relevance of comparative law, argued that it should be used differently.

${ }^{9}$ In the famous Lüth case (1958), as also remarked in Groppi and Ponthoreau, The Use of Foreign Precedents by Constitutional Judges, p. 249, the FCC applied the guarantee of freedom of expression article 5 of the Basic Law - to repeal an injunction issued by a German court against a German politician who had called for a boycott of a movie made by a producer who formerly made Nazi propaganda movies. The decision cites Cardozo's statement according to which freedom of expression is 'the matrix, the indispensable condition of nearly every other form of freedom'. It also cites article 11 of the French Declaration of the Rights of Man and Citizen: 'The basic right to freedom of expression, the most immediate aspect of the human personality in society, is one of the most precious rights of man'.

${ }^{10} 539$ U.S. 558 (2003).

${ }^{11}$ With this decision, the court overruled Stanford v. Kentucky (492 U.S. 361, 1989), which upheld the infliction of capital punishment on criminals who were over 16 years of age at the time they committed the crime.
} 
eralism; a proven balance in political mechanisms through separation of powers; specific guarantees for the accused in criminal cases; and broad provisions to secure individual freedom and preserve human dignity. These doctrines and guarantees are central to the American experience and remain essential to our present-day self-definition and national identity. Not the least of the reasons we honor the Constitution, then, is because we know it to be our own. It does not lessen our fidelity to the Constitution or our pride in its origins to acknowledge that the express affirmation of certain fundamental rights by other nations and peoples simply underscores the centrality of those same rights within our own heritage of freedom.

The opinion of Justice Scalia (joined by Justice Rehnquist and Justice Thomas), however, strongly dissented with the majority, claiming that ' $[t]$ he basic premise of the Court's argument - that American law should conform to the laws of the rest of the world ought to be rejected out of hand'.

Cases like this, and related debates, show how controversial the use of foreign law can be in constitutional adjudication, raising many unanswered questions. On the one hand, there are questions concerning the justification of this practice. In fact, the use of foreign law 'is gaining currency', but its proponents 'rarely offer a firm theoretical justification" ${ }^{\prime 2}$ for it. On the other hand, there are questions concerning how foreign law should be used, and what we should expect from its use.

These questions can receive different answers, indicating different models of adjudication. Following a taxonomy proposed by Vicky Jackson, ${ }^{13}$ we can identify two conflicting models: a convergence model and a resistance model.

The convergence model points towards uniformity, based on a full convergence of constitutional practices, realized through the judicial borrowing of ideas and doctrines from other courts and systems of foreign and international law. Justice Scalia attributes this view ${ }^{14}$ to the majority in Roper, and in other cases such as Lawrence $v$. Texas: ${ }^{15}$

\footnotetext{
${ }^{12}$ Roger P. Alford, 'In Search of a Theory for Constitutional Comparativism', UCLA Law Review 52(639) (2005): pp. 639-714, at p. 639.

${ }^{13}$ Vicki C. Jackson, 'Constitutional Comparisons: Convergence, Resistance, Engagement', Harvard Law Review 119(1) (2005): pp. 109-128.

${ }^{14}$ Ibid.

15539 U.S. 558 (2003).
} 
Constitutional entitlements do not spring into existence because some States choose to lessen or eliminate criminal sanctions on certain behavior. Much less do they spring into existence, as the Court seems to believe, because foreign nations decriminalize conduct.

Indeed, the objective of full convergence may be desirable in many respects, but it disregards constitutional pluralism and the variety of ways in which we can pursue the realization of the constitutional values that are shared by our democracies.

On the other hand, the resistance model, defended by Scalia in Roper and other cases, points to a radical rejection of comparative constitutional adjudication. For instance, he argued against the use of foreign law in radical terms in Atkins v. Virginia ${ }^{16}$ (declaring the unconstitutionality of the death penalty for people with intellectual disabilities) and in Lawrence v. Texas (declaring the unconstitutionality of criminal laws banning homosexual conduct, and overruling precedents established in this respect). In both cases, the majority opinions relied on the law and judicial doctrines of foreign constitutional systems in order to justify the court's decision. Scalia dissented from this approach, claiming that 'foreign sources of law can never be relevant to an interpretation of - to the meaning of - the U.S. Constitution'. ${ }^{17}$ This radical rejection relies on different reasons concerning the quality of judicial decision-making, as well as its political legitimacy, which come from the theoretical background provided by originalist constitutionalism. ${ }^{18}$

\footnotetext{
16536 U.S. 304 (2002).

${ }^{17}$ In Lawrence v. Texas, the majority opinion also stated: 'In the United States, criticism of Bowers has been substantial and continuing, disapproving of its reasoning in all respects, not just as to its historical assumptions. And, to the extent Bowers relied on values shared with a wider civilization, the case's reasoning and holding have been rejected by the European Court of Human Rights, and that other nations have taken action consistent with an affirmation of the protected right of homosexual adults to engage in intimate, consensual conduct'.

${ }^{18}$ Our analysis here will not specifically engage with the originalist-nonoriginalist debate on comparative adjudication, which is primarily concerned with the relationship between the use of foreign law and interpreters' fidelity to original constitutional meaning. More precisely, originalist objections to comparative adjudication are centred on the idea that it compromises the fidelity of constitutional interpretation to the original meaning and, therefore, undermines the legitimacy of constitutional law and adjudication. As we note below, however, there are objections that are not grounded in originalist premises and, yet, point to a resistance model of adjudication based on a more general concern for legal pluralism and democratic-self-government. Our aim is to address such concerns too, and provide a broad defence of the engagement model.
} 
More generally, drawing on a powerful defence of the resistance model provided by Carlos Rosenkrantz, ${ }^{19}$ we can identify three main reasons to resist comparative adjudication: (1) it is incompatible with the nature of constitutional law, and entails the renouncement of self-government in constitutional democracies; ${ }^{20}$ (2) it prevents the establishment of a pluralist constitutional culture; and (3) it makes judicial decisions 'unnecessarily complex and less intelligible' for citizens. To these we may add a further objection that is often raised by critics of comparative adjudication: (4) it favours judicial cherrypicking, and gives too much discretion to courts.

We shall attempt to answer these objections, and defend a third model of adjudication, which Jackson presents as an alternative to both convergence and resistance:

\begin{abstract}
[T] he constitution's interpreters do not treat foreign or international material as binding, or as presumptively to be followed. But neither do they put on blinders that exclude foreign legal sources and experience. Transnational sources are seen as interlocutors, offering a way of testing understanding of one's own traditions and possibilities by examining them in the reflection of others. $^{21}$
\end{abstract}

This is an engagement model, 'centered on judicial dialogue. ${ }^{22}$ We shall defend it in new terms, so as to provide an account of such engagement and its expected outcomes. Then, we shall draw on this account to address the four objections listed above.

\title{
II. AN ENGAGEMENT MODEL
}

Our defence of the engagement model is centred on the following claim: Courts applying constitutional norms - in constitutional democratic systems - achieve better justified decisions in controversial cases if their reasoning takes into account foreign law and the reasons that courts of other jurisdictions offer to justify their own decisions.

When different interpretations of constitutional norms are possible according to the practices of a jurisdiction, a foreign doctrine or precedent either (a) provides new information or conceptual argu-

\footnotetext{
${ }^{19}$ Carlos F. Rosenkrantz, 'Against Borrowings and other Nonauthoritative Uses of Foreign Law', International Journal of Constitutional Law 1(2) (2003): pp. 269-295.

${ }^{20}$ Along the lines of those objections to judicial review that focus on the 'counter-majoritarian difficulty', see Alexander M. Bickel, The Least Dangerous Branch: The Supreme Court at the Bar of Politics (New Haven: Yale University Press, 1986).

${ }^{21}$ Jackson, 'Constitutional Comparisons', p. 114.

${ }^{22}$ Ibid.
} 
ments in favour of a particular interpretation, or (b) sheds light on the aspects that distinguish our own jurisdiction from other jurisdictions, thus providing reasons for a different interpretation. ${ }^{23}$

In this way, the use of foreign law in adjudication works as a contributory condition of better justified decisions. By itself, it is neither a necessary nor a sufficient condition for such decisions, but instead serves to enhance the justificatory process. ${ }^{24}$

These claims suggest the defence of a particular version of judicial dialogue $^{25}$ in which foreign law and the reasoning of foreign courts do not have conclusive or decisive authority, ${ }^{26}$ but rather exert a persuasive authority. ${ }^{27}$ This dialogue amounts to an exchange of arguments between domestic and international courts, in pursuit of a better understanding of what their legal systems have in common and what makes them different.

The goal is not full convergence by means of borrowing, but rather a reasoned convergence on what may bring us together, allowing for reasoned divergence on what makes us legitimately different. This may be the case, for instance, with respect to free speech. In the version we defend, a judicial exchange of arguments would point, on the one hand, to reasonable convergence on the protection of free political speech, but would also allow reasonable divergence on the ultimate principles that justify that freedom, as well as on the forms of speech that should count as hate speech and thus be prohibited. ${ }^{28}$

\footnotetext{
${ }^{23}$ Drawing on Jackson, 'Constitutional Comparisons'. For instance, in a case concerning transsexualism, the Italian Constitutional Court has made reference to a decision of the German FCC, so as to clarify the medical aspects of the issue at stake and support its own conclusions (161/1985). On the other hand, the German FCC, on several occasions, has made reference to foreign doctrines in order to differentiate its own jurisdictions from others such as the Swiss and US jurisdictions (BVerfGE 1, 97 (1951) and BVerfGE 2, 79 (1952)).

${ }^{24}$ On the notion of contributory condition, see Georg Henrik Von Wright, A Treatise on Induction and Probability (London: Routledge \& Kegan Paul, 1951).

${ }^{25}$ The idea draws on Claire L'Hereux-Dubé, 'The Importance of Dialogue: Globalization and the International Impact of the Rehnquist Court', Tulsa Law Journal 34(1) (1998): pp. 15-45.

${ }^{26}$ Joseph Raz, 'Authority, Law and Morality', The Monist 68(3) (1985): pp. 295-324.

${ }^{27}$ As suggested by H. Patrick Glenn, 'Persuasive Authority', McGill Law Journal 32(2) (1987): pp. 261297; and Anne-Marie Slaughter, 'A Global Community of Courts', Harvard International Law Journal 44(1) (2003): pp. 191-219. Concerning the authoritative status of foreign law, see the deep analysis of Schauer, 'Authority and Authorities'.

${ }^{28}$ On the case of hate speech, see e.g. Melissa A. Waters, 'The Role of Transnational Judicial Dialogue in Shaping Transnational Speech: International Jurisdictional Conflicts in Hate Speech and Defamation Law, in Russell A. Miller and Rebecca M. Bratspies (eds.), Progress in International Law (Leiden and Boston, MA: Martinus Nijhoff Publishers, 2008), pp. 473-490. On diversity in - and differences and similarities as foci of - comparative law in general, see Roger Cotterrell, 'Is It So Bad to Be Different?', in Örücü Esin and David Nelken (eds.), Comparative Law: A Handbook (Portland: Hart Publishing, 2007), pp. 133-154.
} 
In what follows, we attempt to provide a justification for a judicial dialogue of this sort. We draw on the ideas of wide reflective equilibrium, public reason and mid-level principles to argue that the use of foreign law in constitutional adjudication is legitimate because it improves our understanding of our own constitutional doctrines and contributes to the exercise of public reason in adjudication.

Before starting, two caveats are in order. First, we focus on the 'optional' use of foreign law and do not address the use of international or EU law that is binding for constitutional courts. Indeed, the debate on comparative adjudication does not always distinguish between the use of foreign law and the use of international law, but this distinction is highly relevant. In fact, obligations deriving from international treaties and agreements make the use of international law legitimate and necessary, due to what our constitutions require (as witnessed by the use, by national courts, of EU law and the decisions of the European Court of Human Rights and the European Court of Justice: these have a direct impact on national legal systems and can modify their norms).

Second, while our background ideas come from the Rawlsian doctrine of justice as fairness, our account of judicial engagement is not fully dependent on that doctrine and does not require us to fully endorse it. In fact, we draw on two Rawlsian ideas - the idea of wide reflective equilibrium and the idea of public reason - to outline a framework for the use of foreign law in adjudication. This framework has a more limited scope than the Rawlsian theory of justice and cuts across that theory accordingly, with respect to Rawls's account of constitutional adjudication. Many other aspects of Rawls's doctrine of justice as fairness - such as his account of distributive justice, or his moral premises, or his idea of the original position are not brought into play by our framework.

Furthermore, our framework combines the ideas of wide reflective equilibrium and public reason with the non-Rawlsian ideas of incompletely theorized agreements and mid-level principles. Accordingly, Rawlsian ideas contribute to our engagement model, but do not exhaust it. Our idea of a judicial engagement centred on mid-level principles fits Rawls's doctrine of justice as fairness, but is not essentially connected to it and may also fit other accounts of the public sphere, such as Habermas's. In fact, with respect to the do- 
main of constitutional law and adjudication, the latter shares with Rawls's doctrine the conception of constitutional law as realizing the most intense institutionalization of practical reason, through an intersubjective justificatory practice that is guided by particularly stringent criteria of mutual recognition. ${ }^{29}$ Both point to a slidingscale exercise of practical reason, which is precisely what our model seeks to capture and address. ${ }^{30}$

\section{A. Reflective Equilibrium, Narrow and Wide}

We start by justifying the use of foreign law in adjudication as a way of improving our understanding of our own constitutional doctrines. The idea is that this contributes to our reasoning about constitutional questions by enriching the set of arguments that we may develop in constructing our solutions to those questions. It allows us, more precisely, to reach justified solutions, in accordance with a conception of practical reason that is due to John Rawls, and gives a prominent role to the method of reflective equilibrium.

Rawls, indeed, has provided us with three notions of justification: ${ }^{31}$ the derivation of principles in the original position, the method of reflective equilibrium, and the idea of public reason. The first notion is extremely important but we shall not dwell on it here, for two reasons: first, it lies at the core of Rawls's theory of justice and is therefore already very well-known; and, second, it is not central to our argument, but rather lies in its background.

Let us focus, first, on reflective equilibrium, and then on public reason.

Although it was already somehow present in Rawls's first works, ${ }^{32}$ Nelson Goodman introduced the idea of reflective equilibrium in philosophy of logic, in order to account for the results of inferential reasoning, both deductive and inductive:

\footnotetext{
${ }^{29}$ As remarked by Frank Michelman, Rawls's 'analytic movement from a highly abstract "original position", through "constitutional" and "legislative" stages, to a "judicial" stage' is close to Habermas's view of constitutional law as 'a political practice of staged discursive precipitation of substantiallyethically inflected institutional rights out of a universal ether of abstract right'. See Frank I. Michelman, 'Family Quarrel', Cardozo Law Review 17 (1995): pp. 1163-1177, on pp. 1175-1176.

${ }^{30}$ We thank an anonymous reviewer for pushing us to clarify this point.

${ }^{31}$ Thomas M. Scanlon, 'Rawls on Justification', in Samuel Freeman (ed.), The Cambridge Companion to Rawls (Cambridge: Cambridge University Press, 2003), pp. 139-167, at p. 139.

32 John Rawls, 'Outline of a Decision Procedure for Ethics', Philosophical Review 60(2) (1951): pp. $177-197$.
} 
I have said that deductive inferences are justified by their conformity to valid general rules, and that general rules are justified by their conformity to valid inferences. But this circle is a virtuous one. The point is that rules and particular inferences alike are justified by being brought into agreement with each other. A rule is amended if it yields an inference we are unwilling to accept; an inference is rejected if it violates a rule we are unwilling to amend. The process of justification is the delicate one of making mutual adjustments between rules and accepted inferences; and in the agreement achieved lies the only justification needed for either. ${ }^{33}$

In A Theory of Justice, Rawls devises a similar method in moral philosophy for justifying our practical decisions. ${ }^{34}$ According to this method, we start from a set of considered judgements (or intuitions, although Rawls does not use this term) and test them against the moral principles that we endorse as most reasonable. If our judgements do not match each other or do not match the principles involved, we revise or sacrifice those judgements or the principles at stake. The process of justification thus amounts to a coherentist exercise working towards establishing a reflective equilibrium among our moral principles and considered judgements: it consists in finding 'a scheme of principles that match people's considered judgements and general convictions in reflective equilibrium'. ${ }^{35}$

Rawls then introduces a distinction that is of crucial relevance for our purposes. He points out that this process can be narrow, if limited to a mutual adjustment between our considered judgements and our moral principles, or wide, if it goes further and tests our considered judgements against the principles of other plausible conceptions of justice: $^{36}$

Furthermore, because our inquiry is philosophically motivated, we are interested in what conceptions people would affirm when they have achieved wide and not just narrow reflective equilibrium, an equilibrium that satisfies certain conditions of rationality. That is, adopting the role of observing moral theorists, we investigate what principles people would acknowledge and accept the consequences of when they have had an opportunity to consider other plausible conceptions and to assess their supporting grounds. Taking this process to the limit, one seeks the conception, or plurality of conceptions, that would survive the rational consideration of all feasible conceptions and all reasonable arguments for them. We cannot, of course, actually do this, but we can do what seems like the next best thing, namely, to characterize the structures of the predominant conceptions familiar to us from the philosophical tradition, and to work out the further refinements of these that strike us as most promising. ${ }^{37}$

\footnotetext{
${ }^{33}$ Nelson Goodman, Fact, Fiction, and Forecast (Cambridge, MA: Harvard University Press, 1955), p. 64.

34 John Rawls, A Theory of Justice (Cambridge, MA: Harvard University Press, 1971), pp. 46-52; and A Theory of Justice, Second Edition (Cambridge, MA: Harvard University Press, 1999), pp. 40-46.

${ }^{35}$ John Rawls, Justice as Fairness: A Restatement (Cambridge MA: Harvard University Press, 2001), p. 288.

${ }^{36}$ A distinction that is not explicit in A Theory of Justice, but which appears in 'The Independence of Moral Theory', Proceedings and Addresses of the American Philosophical Association 47 (1974): pp. 5-22; reprinted in John Rawls, Collected Papers (Cambridge MA: Harvard University Press, 1999).

${ }^{37}$ Rawls, Collected Papers, p. 289.
} 
In this way, the search for a wide reflective equilibrium includes the reasonable views of others within the scope of the justificatory process, so as to allow 'all possible sources of justificatory force to be considered' ${ }^{38}$

A wide reflective equilibrium of this sort allows us to reach better justified decisions. It allows us to take into account not only the different, reasonable principles and doctrines that are upheld in our own community, but also the reasonable alternatives provided by the principles and doctrines upheld in other communities. In the latter, there might be principles that we cannot find in our community. Furthermore, there may be different ways of accommodating a plurality of principles and doctrines. In both of these respects, reaching beyond the doctrines of our own community allows us to improve our understanding of our principles and doctrines, and better justify our way of accommodating them. ${ }^{39}$

The normative idea of reasonableness here puts some constraints on which views of others can be involved, limiting the range of principles and judgements that can be assessed in pursuit of a wide

\footnotetext{
${ }^{38}$ On wide reflective equilibrium, see also Norman Daniels, Justice and Justification: Reflective Equilibrium in Theory and Practice (Cambridge: Cambridge University Press, 1996); 'Reflective Equilibrium', in Edward N. Zalta (ed.), The Stanford Encyclopedia of Philosophy (Winter 2016 Edition), < https:// plato.stanford.edu/archives/win2016/entries/reflective-equilibrium/ $>$. There are two ways of understanding the idea of wide reflective equilibrium. Daniels understands it as an equilibrium between our considered judgements and moral principles, along with broader philosophical ideas. A different way is to understand it as an equilibrium between our considered judgements and the principles of our moral doctrine, along with the principles of other moral doctrines. This second understanding is, for instance, adopted by Scanlon: 'It thus allows all possible sources of justificatory force to be considered'. See Scanlon, 'Rawls on Justification', p. 151. This is the understanding that we are endorsing here. We are indebted to an anonymous reviewer for this journal who rightly requested this clarification.

${ }^{39}$ First, contrasting our own principles and doctrines with other communities' principles and doctrines requires us to expound and shed light on the former, so as to grasp the extent to which they differ from and resemble each other. Second, other communities' principles and doctrines - and the ways in which those communities accommodate them - may point to reasonable alternatives to our own. Searching for a wide reflective equilibrium allows us to consider such alternatives and whether to absorb or to reject them, and then revise or refine accordingly our own doctrines and principles, and how we accommodate them.
} 
reflective equilibrium. As we shall see, these constraints boil down to standards of argumentative reciprocity, as required by reasonableness. Of course, much more could be said on reflective equilibrium ${ }^{40}$ and the arguments against it - but for our purposes the passage quoted above is enough, especially when we consider that Rawls characterizes legal reasoning in similar terms:

[T] he precept that like decisions be given in like cases significantly limits the discretion of judges and others in authority. The precept forces them to justify the distinctions that they make between persons by reference to the relevant legal rules and principles. In any particular case, if the rules are at all complicated and call for interpretation, it may be easy to justify an arbitrary decision. But as the number of cases increases, plausible justifications for biased judgments become more difficult to construct. The requirement of consistency holds of course for the interpretation of all rules and for justifications at all levels. ${ }^{41}$

Of crucial relevance here is the role of coherence in legal justification, which is pivotal 'for all rules... at all levels'. This emphasis on coherence, indeed, allows us to connect the idea of reflective equilibrium to Rawls's account of legal justification, and draw an analogy between moral reasoning and legal reasoning.

In this analogy, Rawls's considered judgements - 'those rendered under conditions favorable to the exercise of the sense of justice ${ }^{, 42}$ find their legal counterpart in judgements - legal considered judgements - that are made under conditions favourable to the knowledge of law. They match legal statutes and judicial precedents and doctrines: in Dworkinian terms, they match the best reconstruction of

\footnotetext{
${ }^{40}$ For excellent presentations, see John Rawls, Political Liberalism (New York: Columbia University Press, 1993); Daniels, Justice and Justification; Daniels, 'Reflective Equilibrium'. For critiques of reflective equilibrium as a method that can realize convergence and stability, see Richard Brandt, $A$ Theory of the Good and the Right (Oxford: Oxford University Press, 1979), pp. 19-22; Richard Brandt, 'The Science of Man and Wide Reflective Equilibrium', Ethics 100(2) (1990): pp. 259-278; Richard M. Hare, 'Rawls' Theory of Justice - II', Philosophical Quarterly 23(92) (1973): pp. 241-252; and more recently, Thomas Kelly and Sara McGrath, 'Is Reflective Equilibrium Enough?', Philosophical Perspectives 24 (2010): pp. 325-359. In broader terms, Gerald Cohen provides a powerful critique of Rawlsian constructivism, pointing out that it gives inappropriate relevance to empirical circumstances in establishing principles of justice. See Gerald A. Cohen, Rescuing Justice and Equality (Cambridge, MA: Harvard University Press, 2008), pp. 232, 261.

${ }^{41}$ Rawls, A Theory of Justice, p. 237; and in the Second Edition at p. 209.

${ }^{42}$ Rawls, A Theory of Justice, Second Edition, p. 42.
} 
legal materials. And the deliberative procedure for achieving this result resembles the coherentist search for a wide reflective equilibrium, requiring us to abandon some precedent or interpretation, or to revise and coherently refine our legal judgements, including on the basis of foreign law. ${ }^{43}$

Let us see, now, how this procedure would apply to a legal case such as Roper. Until 2005, the constitutional legitimacy of the death penalty for juvenile offenders did fit the existing legal materials, that is, the laws in force in twenty-five states and the precedents set by the US Supreme Court. However, only the pursuit of a narrow reflective equilibrium made it difficult to overrule these precedents and take a different direction. Indeed, if we add (again, in Dworkinian terms) a dimension of value (or justification) to the dimension of fit, it makes sense to widen the search for a reflective equilibrium by comparing our laws with the laws of other systems with similar grounds of law. ${ }^{44}$ Let us note, as we will explicate below, that Rawls's account of the 'best interpretation' is close to Dworkin's account, but differs from it in some relevant respects. As in Dworkin's theory, the best interpretation is the one that 'best fits the relevant body of those constitutional materials and justifies it in terms of the public conception of justice'. ${ }^{45}$ Rawls's conception, however, seems to differ from Dworkin's, since it specifies that judges should justify their decisions by appealing 'to the political values covered by the public conception of political justice, or a reasonable variant of this conception', and that they cannot invoke values covered 'by a conception of morality as such, not even of political morality'. ${ }^{46}$

In this way, the search for a wide reflective equilibrium allows us to strongly enrich our interpretation in the dimension of value, by

\footnotetext{
${ }^{43}$ In this way, the idea of wide reflective equilibrium (along with the idea of mid-level principles presented in section 5) allows the engagement model to meet the double burden that it faces as a reflective model of comparative adjudication: it needs to demonstrate how facts about foreign law can contribute to normative judgements, and how foreign law can enrich normative judgements that are ultimately based on domestic attitudes'. See Bosko Tripkovic, 'The Morality of Foreign Law', International Journal of Constitutional Law 17(3) (2019): pp. 732-755, at p. 745. On Rawls and legal reasoning more generally, see also José Juan Moreso, 'El diálogo judicial como equilibrio reflexivo amplio', Anuario de Filosofia del Derecho 34 (2018): pp. 73-93; Chiara Valentini, 'The Reasonable Adjustment of Basic Liberties: Liberalism and Judicial Balancing', European University Institute Max Weber Programme Working Paper 36 (2009).

${ }^{44}$ Ronald Dworkin, Law's Empire (Cambridge, MA: Harvard University Press, 1986), pp. 230-232; Justice in Robes (Cambridge, MA: Harvard University Press, 2006), pp. 14-18.

${ }^{45}$ Rawls, Political Liberalism, p. 236.

${ }^{46}$ Rawls, Political Liberalism, pp. 236-237.
} 
progressively refining and matching our legal considered judgements - along with other legal considered judgements - and the general principles of our constitutional doctrines - along with the principles of other constitutional doctrines. ${ }^{47}$

A recent decision of the Italian Constitutional Court may help to illustrate this point. In deciding whether the Italian Red Cross could be converted from a public law body into a private entity, the court considered the fit between its own judgement and the relevant materials of Italian constitutional law. Furthermore, it tested its own judgement against the principles of its own doctrines as well as against relevant foreign principles and doctrines, so as to refine the former as much as was required for it to match the latter. In cases like this, engagement with foreign law amounts to a comparative analysis enriching the set of elements - doctrines, principles and legal judgements - that fall within the scope of the judicial equilibrium in the justification of the court's decision. ${ }^{48}$

Indeed, testing our judgements and doctrines against possible alternatives allows us to broaden the range of arguments that we may consider and develop while justifying our interpretation of the law. In doing so, we improve our interpretation in both descriptive and deliberative terms. ${ }^{49}$ First, we expose and shed light on our arguments and underlying doctrines by contrasting them with counterarguments and different doctrines. Second, we refine or revise our arguments in the light of reasonable alternatives so as to justify our interpretations, 'as a matter of mutual support of many considerations. ${ }^{50}$ This is, for instance, what the Canadian Supreme Court did in R. v. Keegstra. ${ }^{51}$ The Court made reference to US Supreme Court case law on free speech precisely to articulate - and differentiate - its own approach to hate propaganda: 'just as similarities will justify borrowing from the American experience, differences may require that Canada's constitutional vision depart from that endorsed in the United States'. And this is what the Indian Constitutional Court did too, in the famous case Kesavananda Bharati

\footnotetext{
${ }^{47}$ Rawls, Justice as Fairness: A Restatement, p. 288.

${ }^{48}$ Italian Constitutional Court, decision n. 79/2019.

49 Scanlon, 'Rawls on Justification'.

${ }^{50}$ Rawls, A Theory of Justice, Second Edition, p. 19.

51 [1990] 3 SCR 697.
} 
Sripadagalvaru \& Ors. v. State of Kerala \& Anr. ${ }^{52}$ The Court relied on foreign legal doctrines - Australian, American, Canadian - as part of a wide range of mutually supportive considerations, in order to shed light on the concept of 'amendment' under the Indian Constitution. ${ }^{53}$

Such mutual support makes our interpretations acceptable from different points of view, and therefore amenable to the consensus and relative stability that are required to implement a core set of guarantees and the rule of law at a transnational level, notwithstanding the fact of legal pluralism. And this leads us to another idea of Rawls that is relevant for our purposes: the idea of public reason.

\section{B. Public Reason and Reasonableness as Reciprocity}

In very general terms, the idea of public reason defines the way to reason in the public forum in a pluralist society. In Rawls's account, this involves justifying a particular position by appeal to reasons that people with different moral or political backgrounds could accept: 'our laws and political institutions must be justifiable to each of us by reference to some common point of view, despite our deep differences and disagreements, ${ }^{54}$

In this way, the idea of public reason serves as a standard of legitimacy for our laws and political institutions, and sets the guidelines in accordance with which legislators, judges, and citizens should act in the public forum. ${ }^{55}$ More precisely, it guides the exchange of arguments in the public forum so as to allow consensus, pluralism notwithstanding, and give a certain stability to a just society. ${ }^{56}$ Indeed, it is precisely a concern for stability that prompts this account of public reason.

In A Theory of Justice, Rawls assumes that a well-ordered society, organized according to the principles of justice - the principle of

\footnotetext{
524 SCC 225: AIR 1973 SC 1461.

${ }^{53}$ As remarked in Groppi and Ponthoreau, The Use of Foreign Precedents by Constitutional Judges, pp. 91-93.

${ }^{54}$ Jonathan Quong, 'On the Idea of Public Reason', in Jon Mandle and David A. Reidy (eds.), A Companion to John Rawls (Chichester: Wiley-Blackwell, 2013), pp. 265-280, at p. 265; see also Stephen Macedo, 'The Politics of Justification', Political Theory 18(2) (1990): pp. 280-304.

${ }^{55}$ Quong, 'On the Idea of Public Reason'.

${ }^{56}$ John Rawls, Political Liberalism, Paperback Edition (New York: Columbia University Press, 1996).
} 
equal basic liberties and the difference principle - would be a stable society. ${ }^{57}$ And in a well-ordered, stable society, individuals would have a sense of justice and act upon the principles of justice. Later, in Political Liberalism, Rawls acknowledges that such an account of stability does not take into due consideration the fact of reasonable pluralism. Even in well-ordered societies, individuals may have different ideas concerning fundamental questions, and this may compromise stability. Previously, Rawls's account of stability was suitable for individuals conceiving their autonomy in Kantian terms. ${ }^{58}$ In Political Liberalism, however, one's sense of justice may rest on other views, besides Kantian liberalism, that also qualify as reasonable comprehensive doctrines, such as Millian liberalism, or religious views that accept liberalism. Among such doctrines, indeed, we can establish an overlapping consensus, selecting arguments that can be advanced in the public forum, and admitting only those that fulfil the requirements of reasonableness.

This account of stability thus focuses on the possibility of social cooperation, and identifies the 'reasonable' use of public reason as the best tool for constructing stable agreements that support such cooperation. Public reason is the way to reason about political values, and unfolds according to a standard of reasonableness that enables social cooperation by way of reciprocity: citizens are treated as free and equal, which is the basic understanding of liberal citizenship on which fair cooperation is founded. ${ }^{59}$

The doctrine of public reason, from this perspective, does not apply to controversial questions that ground our political values, but only to questions of basic institutional justice and constitutional essentials with respect to which reasonable comprehensive doctrines may coincide. Public reason, here, requires us to bring into our discussions only political values that 'everyone can be reasonably expected to endorse' and to account for our positions 'in terms of a reasonable balance' of such values, with a shared understanding that 'the plurality of reasonable comprehensive doctrines held by citizens

\footnotetext{
${ }^{57}$ Rawls, A Theory of Justice, p. 454; and in the Second Edition at p. 398.

58 Scanlon, 'Rawls on Justification', p. 159.

59 See also Giorgio Bongiovanni and Chiara Valentini, 'Reciprocity, Balancing and Proportionality: Rawls and Habermas on Moral and Political Reasonableness', in Giorgio Bongiovanni, Giovanni Sartor, and Chiara Valentini (eds.), Reasonableness and Law (Dordrecht: Springer, 2009), pp. 79-107.
} 
is thought by them to provide further and often transcendent backing for those values'. ${ }^{60}$ To illustrate this point, Rawls refers to the case of abortion. In the forum of public reason, our arguments on abortion should appeal to public political values, such as due respect for human life, the ordered reproduction of political society over time, the equality of women as equal citizens. Our arguments, then, should be based on a reasonable balance of such values, 'a balance that can be seen to be reasonable' by others. And a balance is reasonable if it does not exclude a woman's duly qualified right to decide to end her pregnancy in the first trimester. In fact, at an early stage of pregnancy, the political value of the equality of women overrides other values, hence it would be unreasonable to exclude the right that gives force to that value. 'Any comprehensive doctrine that leads to a balance of political values excluding that duly qualified right in the first trimester is to that extent unreasonable' and contrary to the ideal of public reason. ${ }^{61}$

In this way, the idea of public reason applies differently depending on who is using it:

\begin{abstract}
It is imperative to realize that the idea of public reason does not apply to all political discussions of fundamental questions, but only to discussions of those questions in what I refer to as the public political forum. This forum may be divided into three parts: the discourse of judges in their decisions, and especially of the judges of a supreme court; the discourse of government officials, especially chief executives and legislators; and finally, the discourse of candidates for public office and their campaign managers, especially in their public oratory, party platforms, and political statements. We need this three-part division because, as I note later, the idea of public reason does not apply in the same way in these three cases and elsewhere. In discussing what I call the wide view of public political culture, we shall see that the idea of public reason applies more strictly to judges than to others, but that the requirements of public justification for that reason are always the same. ${ }^{62}$
\end{abstract}

Judicial decisions, and the justifications that judges provide for these decisions, are framed by public reason alone: on the sole basis of the political values that, in their judgement, put forward the most reasonable understanding of the public conception of justice and its constituent ideas; or at least a reasonable variant thereof. ${ }^{63}$ Public reason is the only reason that courts exercise in performing their function and applying the constitution.

\footnotetext{
${ }^{60}$ Rawls, Political Liberalism, p. 243.

61 'The only comprehensive doctrines that run afoul of public reason are those that cannot support a reasonable balance of political values'. See Rawls, Political Liberalism, p. 243.

${ }^{62}$ John Rawls, 'The Idea of Public Reason Revisited', The University of Chicago Law Review 64(3) (1997): pp. 765-807, p. 767; Collected Papers, p. 574.

${ }^{63}$ Rawls, Political Liberalism, p. 236.
} 
In a dualist constitutional democracy - which distinguishes constitutional power from legislative and executive power, and distinguishes the supreme law of the land from ordinary laws constitutional courts are the principal institutional tool for upholding the constitution. And this entails a twofold task. On the one hand, they protect the system of constitutionally guaranteed basic rights through constraints posed by the principles of justice. On the other hand, they uphold public reason and give it 'a lasting and adequate form and substance', acting as its 'institutional exemplar'. ${ }^{64}$

From this perspective, courts do not play a merely defensive role, but rather have an active role in giving 'due and continuing effect to public reason': it is their task to put forward 'the best interpretation of the constitution they can', based on their understanding of what constitutional law requires. ${ }^{65}$

In all these respects, Rawls uses the role of courts to illustrate how citizens should likewise behave from the point of view of public reason:

Recall that public reason sees the office of citizen with its duty of civility as analogous to that of judge with its duty of deciding cases. Just as judges are to decide cases by legal grounds of precedent, recognized canons of statutory interpretation, and other relevant grounds, so citizens are to reason by public reason and to be guided by the criterion of reciprocity, whenever constitutional essentials and matters of basic justice are at stake. Thus, when there seems to be a stand-off, that is, when legal arguments seem evenly balanced on both sides, judges cannot resolve the case simply by appealing to their own political views. To do that is for judges to violate their duty. The same holds with public reason: if, when stand-offs occur, citizens simply invoke grounding reasons of their comprehensive views, the principle of reciprocity is violated. From the point of view of public reason, citizens must vote for the ordering of political values they sincerely think the most reasonable. Otherwise they fail to exercise political power in ways that satisfy the criterion of reciprocity. ${ }^{66}$

As this passage makes clear, the idea of reciprocity serves as a criterion that guides the exercise of public reason by citizens as well as judges, in relation to the comprehensive conceptions - and arguments, claims and solutions - that can be used by rational agents

\footnotetext{
${ }^{64}$ Rawls, Political Liberalism, p. 235. More specifically, the court is 'the highest judicial interpreter but not the final interpreter - of the higher law' and 'the exemplar of public reason'. This account is grounded in a conception of constitutional democracy that differentiates between ordinary power and constituent power: ordinary law and the higher law of the people. A supreme court is part of such a dualist system as long as it serves as an 'institutional device that protects the higher law' (in a footnote, Rawls recalls Ackerman's distinction between constitutional law and constitutional politics). Judicial review is not anti-democratic: it is grounded in the 'higher authority of the people'; and it is not antimajoritarian if it 'reasonably accord(s)' with the constitution as the higher law of the people.

${ }^{65}$ There is a further aspect of courts as exemplars of public reason: they give 'vitality and vividness' to public reason, through reasonable interpretations of the constitution. And in the forum of constitutional adjudication, reasonableness requires assessing reasons and arguments under the criterion of argumentative reciprocity that we mentioned before.

${ }^{66}$ Rawls, 'The Idea of Public Reason Revisited', p. 797; Collected Papers, p. 605.
} 
in order to assess and decide questions concerning constitutional essentials and matters of basic justice.

In this sense, the standard of 'reasonableness as reciprocity' constrains the spectrum of reasons and claims that can be advanced and assessed in the forum of public reason and, therefore, in the forum of constitutional adjudication. This standard requires that all rational agents involved in the exercise of public reason proceed by 'changing roles' with their counterparts in the deliberative process, and accept the consequences of the final decision. ${ }^{67}$ Public justification 'is not simply valid reasoning, but argument addressed to others: it proceeds correctly from premises we accept, and think others could reasonably accept, to conclusions we think they could also reasonably accept ${ }^{68}$ In the judicial forum, then:

A Supreme Court justice deciding on a gay marriage law would violate public reason were she to base her opinion on God's forbidding gay sex in the book of Leviticus, or on a personal spiritual revelation that upholding such a law would hasten the end of days. This is because not all members of society can reasonably be expected to accept Leviticus as stating an authoritative set of political values, nor can a religious premonition be a common standard for evaluating public policy. These values and standards are not public. ${ }^{69}$

It is time, now, to apply this model of public deliberation and justification to judicial dialogue and the use of foreign law in constitutional adjudication.

\section{WIDE REFLECTIVE EQUILIBRIUM, PUBLIC REASON AND JUDICIAL DIALOGUE}

Let us imagine that the supreme courts of constitutional democracies, and international courts, regard themselves as part of a 'community' of courts $^{70}$ engaged in joint deliberation. ${ }^{71}$ What kind of

\footnotetext{
${ }^{67}$ On this reading of reasonableness as argumentative reciprocity, see also Bongiovanni and Valentini, 'Reciprocity, Balancing and Proportionality', pp. 93-95.

${ }^{68}$ Rawls, Collected Papers, p. 594.

${ }^{69}$ Leif Wenar, 'John Rawls', in Edward N. Zalta (ed.), The Stanford Encyclopedia of Philosophy (Spring 2017 Edition), < https://plato.stanford.edu/archives/spr2017/entries/rawls/>.

${ }^{70}$ Slaughter, 'A Global Community of Courts'. A conception that may be grounded in the idea of an international community based on the constituent powers of states: an international community of free and equal human beings, as suggested by Matthias Kumm, 'Constituent Power, Cosmopolitan Constitutionalism, and Post-Positivist Law', International Journal of Constitutional Law 14(3) (2016): pp. 697711.

${ }^{71}$ Drawing on Michael E. Bratman, Shared Agency: A Planning Theory of Acting Together (Oxford: Oxford University Press, 2014), ch. 7; although a deliberative practice of this sort may also be grounded, as pointed out above, in the Habermasian idea of dialogue. See Jürgen Habermas, Faktizität und Geltung (Frankfurt am Main: Shurkamp Verlag, 1992); and 'Reconciliation through the Public Use of Reason: Remarks on John Rawls's Political Liberalism', Journal of Philosophy 92(3) (1995): pp. 109-131.
} 
deliberation is this? Here, the idea of wide reflective equilibrium may help.

Sometimes, in controversial cases, judges find out that their precedents, as well as acceptable interpretations of constitutional norms, are not conclusive. There are many possible ways of solving a case, and each of them may fit all the relevant domestic doctrines and precedents. Also, there can be different ways for a judge to reach a reflective equilibrium between his or her considered judgements about the case, the acceptable interpretations, and the principles governing constitutional practice in that jurisdiction.

At this point, as we remarked before, we need to distinguish two dimensions in the application of the law: besides the dimension of fit, there is also the dimension of justification. ${ }^{72}$ In the dimension of fit, judges do not produce conclusive arguments. In order to do so, they must move to the dimension of justification, where reflective equilibrium plays a crucial role. Here, they must find out the most coherent way of harmonizing the relevant legal materials with the principles that provide the best reconstruction of their constitutional practice. If, in performing this task, they look just at their own constitutional practice, they reach a narrow reflective equilibrium. But if they also look at foreign law and the decisions of the supreme courts of other jurisdictions, or international courts, they can reach a wide equilibrium. This doesn't mean that the deliberative process ultimately borrows the solutions established by other doctrines. Rather, courts must always decide their own cases, in their own jurisdictions. Nevertheless, they must engage in a reasoned deliberation. This is a deliberation that takes the arguments of others into account, pursuing a wide reflective equilibrium that, as we stressed above, brings new insights into domestic precedents and new interpretations of constitutional norms.

At this point, however, we may ask which arguments should be brought to bear. Which doctrines should we engage with? How wide and deep should the joint deliberation be?

Let us draw on Rawls's ideas about public reason, and its constraints, to clarify our view in this respect.

First, the scope of the joint deliberative process that lies at the core of judicial dialogue must be limited, so as to involve only courts that

\footnotetext{
${ }^{72}$ Dworkin, Law's Empire, pp. 230-232; Justice in Robes, pp. 14-18.
} 
operate in constitutional democratic systems. Indeed, only views expressed by such systems can be reasonable in Rawlsian terms. This means that, for instance, we cannot include views founded on the idea of the superiority of one race or religion, such as the political doctrines of Francoism or systems that apply Sharia. This does not imply, however, that religious freedom should be regulated in only one specific way: the spectrum of reasonable doctrines and regulations is wide, ranging from laicist doctrines, such as the French, to doctrines that recognize the monarch as the supreme religious authority, such as the British. In any case, respect for basic liberties requires the law to permit membership of any religion or no religion at all, as well as a right of exit.

Second, the idea of public reason requires us to accept a further restriction: not every aspect of foreign constitutional doctrines can be admitted into the public forum, since not every aspect of those doctrines can pass the test of public reason. For instance, the deliberative exchange that we defend would not pursue convergence on the particular conception of secularism that underlies the French doctrine prohibiting religious symbols in public schools. The comprehensive view that grounds this conception, although endorsed by the French constitutional system, is not the only view compatible with religious freedom. There are other reasonable views - for instance, the view that grounds the German doctrine ${ }^{73}$ - which justify other, reasonable, conceptions of secularism and other ways of respecting religious freedom.

Indeed, looking beyond the doctrines upheld in our own community contributes to finding out our own, justified, response to the legitimacy-difficulties that arise from pluralism in our own community. The search for a wide reflective equilibrium, in the exercise of public reason, allows us to consider the reasonable responses given by other communities, which may suggest alternative ways of accommodating the plurality of principles and doctrines that we uphold in our own community. Contrasting our own response with the responses of other communities prompts us to shed light on the former so as to grasp the extent to which, and the aspects under which, they differ from and resemble each other. By this means, first, we become more aware of the plurality of doctrines held in our own

\footnotetext{
${ }^{73}$ The German conception does not exclude religion from public life, but instead allows for the recognition of churches as bodies of public law.
} 
community and what kind of connections we may establish between them. Second, we can consider how to refine and revise such connections in the light of reasonable alternatives that we may wish to assimilate in the response adopted by our own community. As we shall see, centring this justificatory process on mid-level principles ultimately allows us to do this. It allows us to intersect those reasonable alternatives so as to achieve better justified solutions. ${ }^{74}$

And this idea, perhaps, may also account for the controversial doctrine of the margin of appreciation, as applied by the European Court of Human Rights. ${ }^{75}$ According to this doctrine, the member states of the ECHR take their legislative, administrative and judicial actions under the supervision of the court, but enjoy a degree of discretion. The court, in fact, takes into account that the member states may interpret the convention differently, given their different legal cultures.

This sort of public-reason-based pluralism may find an especially strong defence in Raz's idea of simultaneous interpretive pluralism:

What is needed is an interpretation of universal standards, such as the basic principles of human rights, in a way that allows for diverse correct interpretations of their requirements and applications in different circumstances. Call this simultaneous interpretive pluralism, namely, a method of, or approach to, interpretation allowing that incompatible interpretations can all be valid at the same time and in the hands of the same court. To a degree, the European Court of Human Rights, in interpreting the European Convention of Human Rights, allows for such interpretive pluralism through its doctrine of a margin of appreciation. ${ }^{76}$

Third, and relatedly, the idea of public reason suggests that the search for a wide reflective equilibrium may have a limited depth, besides a limited scope. Judicial engagement with foreign law does not need to cover the whole normative spectrum of domestic and foreign constitutional doctrines, from ultimate principles to very specific regulations. Its focus is on 'constitutional principles on high or intermediate levels of abstraction or on some quite specific details'. 77 From the point of view of public reason, this focus should be at the level of abstraction that allows constitutional adjudication

\footnotetext{
${ }^{74}$ We thank an anonymous reviewer for prompting us to clarify this point.

${ }^{75}$ For the different ways in which the court has used this doctrine see e.g. George Letsas, $A$ Theory of Interpretation of the European Convention of Human Rights (Oxford: Oxford University Press, 2007), pp. 8098. The court applied this doctrine for the first time in Handyside $v$ United Kingdom (1976).

${ }^{76}$ Joseph Raz, 'The Future of State Sovereignty', in Wojciech Sadurski, Michael Sevel, and Kevin Walton (eds.), Legitimacy: The State and Beyond, (Oxford: Oxford University Press, 2019), pp. 69-81, at p. 81.

${ }^{77}$ Mark Tushnet, 'The Inevitable Globalization of Constitutional Law', Vanderbilt Journal of International Law 49 (2008): pp. 985-1006, at p. 987.
} 
to pursue a wide reflective equilibrium and, at the same time, produce results that could be accepted by different constitutional doctrines. This, we claim, is a middle level, where judicial deliberations centre on mid-level principles: ${ }^{78}$ standards with a limited scope and level of abstraction, that can be shared by different constitutional doctrines. At this level, for instance, judicial engagement with foreign law would not need to cover either the ultimate principles that ground French or German secularism, or the specific regulations of religious symbols in schools adopted in France or Germany. Rather, such engagement should focus on intermediate standards, such as the standard of religious freedom that, for instance, grants the right to practice a religion to all workers. A standard of this sort, in fact, may be shared by different systems compatibly with the ultimate principles underlying French or German secularism, as well as with the different, specific, regulations enacted in France or Germany. In this way, the idea of public reason is useful to the extent that it is able to accommodate and deepen the different views that are already held in a particular community.

Let us develop this argument. To this end, we shall rely on the doctrine of public reason and the closely related idea of overlapping consensus.

\section{FROM JUDICIAL DIALOGUE TO OVERLAPPING DOCTRINES}

In our previous discussion, we stressed that the exercise of public reason allows for the establishment of an overlapping consensus among reasonable comprehensive doctrines, so as to ensure stable cooperation between free and equal citizens. It is an overlapping consensus, for it amounts to an intersection among different and potentially conflicting - doctrines, realized through an exchange of arguments that fulfils the requirements of reasonableness. ${ }^{79}$

\footnotetext{
${ }^{78}$ Henry Sidgwick, Practical Ethics: A Collection of Addresses and Essays (Oxford: Oxford University Press, 1998); Robert Audi, The Good in the Right: A Theory of Intuition and Intrinsic Value (Princeton, NJ: Princeton University Press, 2004), pp. 165-169.

79 An intersection of this sort is the kind of consensus that we may expect from judicial dialogue. The idea of overlapping consensus, as is well known, is defined as a 'sufficiently inclusive concordant fit among political and other values', occurring among '[comprehensive] doctrines, both religious and nonreligious, that support a political conception of justice underwriting a constitutional democratic society whose principles, ideals, and standards satisfy the criterion of reciprocity'. See Rawls, Collected Papers, p. 608. And 'in such a consensus, the reasonable comprehensive doctrines endorse the political conception' of justice as fairness 'each from its own point of view'. See Rawls, Political Liberalism, Paperback Edition, p. 134.
} 
From the same perspective, Cass Sunstein has introduced the idea of incompletely theorized agreements, conceived as agreements that 'sometimes [...] do involve abstractions, accepted amid severe disagreements on particular cases', although they 'sometimes [...] involve concrete outcomes rather than abstractions'. ${ }^{80}$ So they sometimes also involve mid-level principles, despite disagreement about both general theory and particular cases.

A combination of these ideas, we think, can offer a plausible account of the kind of dialogue and convergence that we should expect from judicial engagement with foreign law: a reasonable intersection among constitutional doctrines. More precisely, an intersection with a reasonable scope and depth.

The ideas of overlapping consensus and incompletely theorized agreements are indeed closely related, ${ }^{81}$ for they both express the possibility of an intersection of this sort: a stable consensus in the face of diverse comprehensive views. These ideas, however, have different scopes of application. Sunstein argues that the idea of overlapping consensus refers to a consensus on political abstractions, whereas incompletely theorized agreements are also meant to capture partial consensus on particulars, notwithstanding disagreement at an abstract level. According to this reading, Rawls's 'overlapping consensus' would allow liberal people who endorse different political views to converge on 'political abstractions' ${ }^{82}$ and abstraction, here, would be the 'way of continuing public discussion when shared understandings of lesser generality have broken down'. From this perspective, Sunstein argues that the idea of overlapping consensus does not always apply to the legal domain. When it comes to legal discourse, we must reasonably agree on 'particulars', and we are therefore called to exercise public reason at a low level of abstraction. ${ }^{83}$ For this reason, we should work towards incompletely theorized agreements, rather than overlapping consensus.

Such agreements, in fact, would be apt to provide legal solutions to political conflicts: 'the distinctly legal solution is to produce agreement on particulars' when there is disagreement on general

\footnotetext{
${ }^{80}$ Cass Sunstein, Legal Reasoning and Political Conflict (New York: Oxford University Press, 1996), p.

${ }^{81}$ Sunstein, Legal Reasoning and Political Conflict, p. 47.

${ }^{82}$ Ibid.

${ }^{83}$ Cass Sunstein, 'Incompletely Theorized Agreements', Harvard Law Review 108(7) (1995): pp. 17331772 , at p. 1735 .
} 
principles. The level of abstraction required by legal reasoning, in fact, is usually lower than the level required by political reasoning: in legal adjudication, practical reasoning is concerned with cases, and therefore deals with the 'concretization' of normative conflicts. ${ }^{84}$

However, we question this line of reasoning. If there is a difference between overlapping consensus and incompletely theorized agreements, it does not lie, as Sunstein claims, in the different levels of abstraction at which they can be established. ${ }^{85}$ In fact, both forms of partial consensus can be abstract as well as concrete. An overlapping consensus is compatible with the 'conceptual descent' that is often required by legal reasoning. ${ }^{86}$ It is a format for agreements at the level of abstraction that is needed, from time to time, in order to reach reasonable solutions. Rawls does not specify the required level of abstraction for judicial reasoning: his perspective entails a judicial discourse that unfolds at different levels, because this is what reasonableness requires when it prescribes that legal discourse comes close to experience and concrete needs. In this sense, we can devise a sliding-scale exercise of public reason, involving an exchange of arguments and reasons whose theoretical density can be adjusted so as to fit the degree of abstraction required by legal reasoning and judicial dialogue, in order to work towards a reasonable overlap of doctrines. Indeed, when it comes to searching for agreements at a low level of abstraction, in spite of disagreements at a higher level, there is no need to abandon the Rawlsian idea of overlapping consensus. We have to apply this idea reasonably, that is, by adjusting the level of abstraction at which this consensus must be achieved. ${ }^{87}$

Thus, in all the cases that we have mentioned so far - from free speech to religious freedom; from abortion to gay marriage - the quest for a reasonable overlap of doctrines in the judicial forum would of course require a court to engage only with arguments that

\footnotetext{
${ }^{84}$ Sunstein, Legal Reasoning and Political Conflict, pp. $46 \mathrm{ff}$.

${ }^{85}$ See also Valentini, 'The Reasonable Adjustment of Basic Liberties'; and Le ragioni della Costituzione (Torino: Giappichelli, 2011), pp. 241-243, 317-318.

${ }^{86}$ Sunstein, Legal Reasoning and Political Conflict, pp. $50 \mathrm{ff}$.

${ }^{87}$ See also Valentini, 'The Reasonable Adjustment of Basic Liberties', p. 19: 'The high level of abstraction that Rawls refers to with regard to political discourse, must be narrowed down when it comes to constitutional adjudication. Here, the veil of ignorance is almost completely lifted and the constraints of reasonableness are strongest'. Therefore judicial reasoning unfolds within the boundaries prescribed by the normative idea that, in the applicative dimension, the abstract form of the law should be adapted to concrete needs. On reasonableness in legal reasoning, see Neil MacCormick, Legal Reasoning and Legal Theory (New York: Clarendon Press, 1994).
} 
fall within the scope of public reason. This, however, would not be incompatible with keeping the judicial focus on principles that, within that scope, display the mid-level of abstraction that is required in order to establish a reasonable overlap of constitutional doctrines on judicial cases. Mid-level principles - such as free political speech, the right of all workers to practice a religion, women's right to end pregnancy in the first trimester, and the legitimacy of gay marriage may well serve as the focus of a reasonable overlapping consensus, which does not need to go deeper and reach the ultimate principles that ground the different doctrines involved.

From this perspective, the idea of overlapping consensus - and the idea of incompletely theorized agreements - may allow us to identify two complementary ways of producing a partial convergence of constitutional doctrines: (a) by moulding the scope, and (b) by adjusting the depth of our deliberation.

If we proceed by moulding the scope, we limit the pursuit of convergence to some doctrines that pass the test of public reason, in spite of their divergence from other doctrines with which we cannot agree in reasonable terms, that is, in terms of argumentative reciprocity. Let us return to our example of religious freedom.

On the one hand, we can mould the scope of our deliberation and pursue convergence on the protection of religious freedom among reasonable doctrines, excluding doctrines that do not pass the test of public reason. For instance, the French or Turkish doctrines can be involved in the pursuit of convergence with other reasonable doctrines, based on different conceptions of laicism, such as the German doctrine. By contrast, doctrines that do not pass the test of reasonableness, such as doctrines based on the idea of the superiority of one religion over all others, are excluded from our deliberation.

On the other hand, we can also adjust the depth of our deliberation so as to pursue convergence at a certain level of abstraction, in spite of divergence at a higher or lower level. In our example, we can pursue convergence on religious freedom, despite reasonable divergence in the conceptions of secularism that ground it in the French, Turkish and German doctrines. In the same vein, we can pursue convergence on religious freedom despite divergence within the plurality of reasonable ways in which the French, Turkish and 
German doctrines protect such freedom, for instance when it comes to the use of religious symbols in public schools.

What, then, is the scope and degree of convergence that a joint deliberation among courts should aim at? Here we can again draw on the idea of incompletely theorized agreements.

There are, in fact, different types of incompletely theorized agreements': incomplete agreements on particular outcomes, on general principles, and also on mid-level principles. ${ }^{88}$

Incomplete agreements of the first type concern particular outcomes and the low-level principles that underlie them. A particular outcome is the ruling of a specific case, and a low-level principle is the ratio of that ruling. Agreements of this type allow us to agree on what to do in particular cases, in spite of disagreement on more abstract principles. And these are especially relevant in the legal domain, where we very often need particularized agreements. That is, we need to agree on how to solve specific controversies, but do not need to converge on the theories and general principles that ground that solution. For instance, we may have agreement on racial quotas for college admissions, but disagreement on the large-scale theory of equality that justifies them. Likewise, to take our examples, there may be agreement on the use of specific religious symbols in schools, but disagreement on the ultimate principles that justify religious freedom, or there may be agreement on the prohibition of 'fighting words' but disagreement on the ultimate principles that ground free speech and the regulation of hate speech.

Incomplete agreements of the second type are agreements on general principles that are not particularized; that is, they obtain with respect to some general principle but do not cover what that principle requires in a particular case. This, for instance, is what happens when there is agreement on a large-scale theory of religious freedom but disagreement on the regulation of religious symbols in schools, or there is agreement on large-scale theories of equality and free speech, but disagreement on quotas for gender boardroom diversity or the legitimacy of flag burning.

There is, then, a third type of incomplete agreement concerning mid-level principles. These are agreements reached at an intermediate' level of abstraction, covering neither the level of general

\footnotetext{
${ }^{88}$ Sunstein, Legal Reasoning and Political Conflict; and 'Constitutional Agreements without Constitutional Theories', Ratio Juris 13(1) (2000): pp. 117-130.
} 
theories, nor the level of specific solutions to particular cases. An agreement of this sort would allow us to converge on the mid-level principle of granting to all workers the right to practice a religion, despite diverging on the principles that ground this right and the specific regulations concerning the possibility for teachers to wear religious symbols at school. Likewise it would allow us to agree on the principle of avoiding racial and gender discrimination, despite disagreement on the underlying large-scale theory of equality, as well as on the specific affirmative action programmes to be enacted by the government. And this is also the type of agreement that would occur in the case of free speech that we used to illustrate the convergence that our engagement model would pursue: a convergence on free political speech, in spite of divergence on the underlying ultimate principles, as well as on the forms of speech that should count as hate speech and thus be prohibited.

Indeed, this is the kind of incompletely theorized agreement that seems more in keeping with the exchange between courts and the cross-fertilization of constitutional doctrines:

This is the kind of outcome more reasonably to be expected from a heterogeneous group of judges, ill-equipped to think about first principles, and working in a more or less ad hoc way from particular situations. ${ }^{89}$

A 'heterogeneous group of judges' who are called to work on particular cases and 'can hardly hope to come to rational agreement', may wish to 'remain as far as possible in the region of middle axioms'. ${ }^{90}$ This is the region of mid-level principles that allow us to mediate between ultimate, foundational principles and intuitions about cases. ${ }^{91}$ For our purposes, the relevant mid-level principles are those principles of our constitutional doctrines (and reasonable variants thereof) that - with a limited scope or a limited degree of abstraction - mediate between the most fundamental principles that ground the doctrines (and their variants), and the more specific rules and precedents that derive from them.

\footnotetext{
${ }^{89}$ Sunstein, Legal Reasoning and Political Conflict, p. 92.

${ }^{90}$ Sidgwick, Practical Ethics, p. 7. As stressed by Sissela Bok, Sidgwick adopted the term 'middle axiom' from John Stuart Mill, 'who distinguished "axiomata media” or intermediate principles, on the one hand, from empirical laws resulting from simple observation and, on the other, from the highest generalizations', and also referred, in this respect, to Francis Bacon's idea of intermediate axioms, found in the Novum Organon. See Sissela Bok, 'Introduction', in Henry Sidgwick, Practical Ethics (Oxford: Oxford University Press, 1998), p. x; John Stuart Mill, A System of Logic, Ratiocinative and Inductive (New York: Harper \& Brothers, 1867), p. 544.

${ }^{91}$ Audi, The Good in the Right, pp. 165-169; Sunstein, Legal Reasoning and Political Conflict, pp. 36-38.
} 
Such principles lie at the core of the kind of judicial dialogue that we defend: they are the focus of the joint deliberation and judicial engagement with foreign law devised in the previous sections. This deliberation, indeed, points to an intersection among reasonable constitutional doctrines, relying on a 'reflection in the middle': going back and forth 'between the highest level principles or the basic values and, on the other hand, individual cases ${ }^{, 92}$ in pursuit of a wide reflective equilibrium.

At this point, however, we should clarify how mid-level principles contribute to this deliberative process.

\section{OVERLAPPING DOCTRINES AND MID-LEVEL PRINCIPLES}

The idea of mid-level principles has been used, in moral and legal philosophy, to define norms that serve as a bridge between abstract principles and specific rules. They are connective principles, which can play a central role in reasoning about moral questions ${ }^{93}$ as well as legal questions. ${ }^{94}$ They mediate between ultimate principles and intuitions about cases, and thereby provide a middle ground for justification when it is hard to agree on the former and it is not enough to agree on the latter.

The fact that mid-level principles are connective and mediate between foundational principles and specific rules does not mean that they always derive by deduction or specification from higherlevel principles. In fact, they can come from balancing or blending higher-level principles. ${ }^{95}$ They can, in other words, be the result of mutual adjustments among higher-level principles that they partially incorporate and partially differ from.

On this basis, we can distinguish derivative from comparative midlevel principles. The first directly emanate from the ultimate principles of comprehensive doctrines. The second, by contrast, indirectly emanate from those principles, being the result of crossfertilizing - by balancing or blending - different, ultimate principles:

\footnotetext{
92 Audi, The Good in the Right, p. 164.

93 Audi, The Good in the Right, pp. 165-169.

${ }^{94}$ Michael D. Bayles, 'Mid-Level Principles and Justification', Nomos 28 (1986): pp. 49-67; Kenneth Henley, 'Abstract Principles, Mid-Level Principles, and the Rule of Law', Law and Philosophy 12(1) (1993): pp. 121-132; Sunstein, Legal Reasoning and Political Conflict, pp. 36-38.

95 Bayles, 'Mid-Level Principles and Justification', p. 56.
} 
a result that is based on them and, at the same time, goes beyond them.

An example is the principle of clear and present danger, according to which a government may not regulate speech unless it can show a clear and present danger. This principle is based on balancing the higher-level principle of free speech against other considerations, and thus counts as a comparative mid-level principle. ${ }^{96}$

Furthermore, mid-level principles can be substantive - when concerning what deserves legal protection - or procedural - when concerning how to realize such protection. The principle of clear and present danger is an example of a substantive mid-level principle, along with the principle of free political speech and the prohibition of racial and gender discrimination. The principle of proportionality ${ }^{97}$ and the principle of equality of arms may be examples of procedural mid-level principles.

In these different forms, mid-level principles may serve as the deliberative focus of judicial engagement with foreign law: an engagement that indicates a wide reflective equilibrium, as devised in the previous sections. Comparative legal reasoning, in this way, is a reflection on legal questions that goes back and forth between specific rulings and abstract principles, so as to mutually adjust them at a middle level and shed light on the common ground between different constitutional doctrines, as public reason requires. Indeed, 'it is doubtful' that 'the top and the bottom', in moral and legal reasoning, can be 'either a starting point or a resting point without some form of cross-fertilization and mutual development'. ${ }^{98}$ When legal reasoning is concerned with the pursuit of a wide reflective equilibrium, under the constraints of reasonableness as reciprocity, this mutual development boils down to the emergence and pro-

96 Ibid.

97 On the principle of proportionality, see Robert Alexy, A Theory of Constitutional Rights (Oxford: Oxford University Press, 2010), pp. 66-69, who argues that the nature of principles implies the principle of proportionality and vice versa'. As such, this principle guides the application of constitutional principles as a standard that requires us to apply them according to the criteria of adequacy, necessity and proportionality stricto sensu. These criteria guide the application of principles throughout the three steps of a judicial test of proportionality that was first applied by the German FCC and has since spread globally, across constitutional systems that find in it a common ground, despite their differing background accounts of constitutional principles and adjudication. See Alec Stone Sweet and Jud Mathews, 'Proportionality Balancing and Global Constitutionalism', Columbia Journal of Transnational Law 47(1) (2008): pp. 73-165.

98 Tom L. Beauchamp, 'Principlism and Its Alleged Competitors', Kennedy Institute of Ethics Journal 5(3) (1995): pp. 181-198, at p. 192. See also Henry S. Richardson, Practical Reasoning about Final Ends (Cambridge: Cambridge University Press, 1994), pp. 176-177. 
gressive refinement of a set of principles that mediate between the ultimate principles of different constitutional doctrines and the precedents and cases of different jurisdictions. Think, for instance, of the principle of proportionality. Gradually, the exchange between courts on the interpretation of rights and their limitation clauses has produced convergence on a mid-level principle that sets some criteria (suitability, necessity and proportionality stricto sensu) for reviewing interferences with rights, in spite of disagreements about the ultimate principles that ground the protection of such rights, as well as about specific rulings based on those criteria. ${ }^{99}$

Mid-level principles of this sort, however, are not a mere product of judicial dialogue. They also prompt it and contribute to its development, being justificatory levers that work in conditions of pluralism, where public reason requires us to provide arguments that others can accept. Drawing on existing accounts of mid-level principles, ${ }^{100}$ we can identify three virtues that make them suited to playing this role, and also add a fourth virtue.

First, mid-level principles have the virtue of convergence: 'since quite different theories converge on many of the same mid-level principles, constructive argument can proceed by refining the application of these principles, and the principles themselves are more certain than any particular theory'. ${ }^{101}$ As we pointed out earlier, agreement on a set of mid-level principles may prompt convergence, along with a progressive refinement of their applications.

Second, they have practical virtues. Mid-level principles enable us to identify morally or legally relevant considerations and, at the same time, to single out relevant normative questions: they 'enable us to identify morally or legally relevant characteristics and to note specific normative questions both more dependably and more quickly than

\footnotetext{
${ }^{99}$ On establishing a common standard of review based on this procedural principle, see Stone Sweet and Mathews, 'Proportionality Balancing and Global Constitutionalism', p. 80, who define proportionality as a 'global constitutional standard'. See also inter alia Aharon Barak, Proportionality: Constitutional Rights and Their Limitations (Cambridge: Cambridge University Press, 2012), pp. 175-210; Vicki C. Jackson, 'Constitutional Law in an Age of Proportionality', Yale Law Journal 124(8) (2015): pp. 30943196; David M. Beatty, The Ultimate Rule of Law (Oxford: Oxford University Press, 2004) and Moshe Cohen-Eliya and Iddo Porat, Proportionality and Constitutional Culture (Cambridge: Cambridge University Press, 2013), ch. 1.

${ }^{100}$ Bayles, 'Mid-Level Principles and Justification'; Henley, 'Abstract Principles, Mid-Level Principles, and the Rule of Law'; Sunstein, Legal Reasoning and Political Conflict, pp. 36-38; Audi, The Good in the Right, pp. 165-169.

${ }^{101}$ Henley, 'Abstract Principles, Mid-Level Principles, and the Rule of Law', p. 123.
} 
we could if directly applying a fundamental principle or theory' ${ }^{102}$ By allowing us to converge and identify relevant considerations, midlevel principles provide guidance and contribute to legal certainty and stability in the face of pluralism.

Third, mid-level principles have the virtue of constraint. They relate to comprehensive doctrines through mechanisms of justification in which the justificatory lever lies with mid-level principles as much as it does with fundamental principles. ${ }^{103}$ Indeed, the relationship between mid-level and fundamental principles is based on mechanisms of specification and reformulation, working at a foundational and also at an intermediate normative level. ${ }^{104}$ In the latter case, mid-level principles contribute to expounding the content and weight of the foundational principles of constitutional doctrines, and in so doing, also serve as constraints, for they prompt us to show our commitment to those foundational principles and doctrines. ${ }^{105}$ They prompt us to clarify if, and to what extent, we endorse the principles that ground our doctrines and, on the other hand, the legal solutions that draw on those principles and apply to specific issues and problems.

On this basis, we can add a fourth virtue of mid-level principles: the explicatory virtue that they display by prompting us to expose and clarify the ultimate principles and concrete rulings that mid-level principles connect, specify and generalize.

Now, we shall draw on this account of judicial dialogue and midlevel principles as its deliberative focus in order to answer the main objections to comparative constitutional adjudication.

\section{OBJECTIONS AND REPLIES}

We previously identified four main objections that may be advanced against comparative constitutional adjudication. First, there is the

\footnotetext{
${ }^{102}$ Henley, 'Abstract Principles, Mid-Level Principles, and the Rule of Law', p. 124.

${ }^{103}$ Henley, 'Abstract Principles, Mid-Level Principles, and the Rule of Law', p. 123.

104 'Mid-level principles and their weightings connect to underlying theory not only through justification with the justificatory work done by the fundamental level but they also connect to theory through specification, with the specifying done by the mid-level principles'. See Henley, 'Abstract Principles, Mid-Level Principles, and the Rule of Law', p. 123.

${ }^{105}$ As Henley points out, 'with only very abstract principles at play, almost any course of action is colorable as justified. The specification of the content of abstract principles through mid-level principles pulls the ropes tighter. And so in addition to its other virtues, justification by mid-level principles has constraint virtues'. See Henley, 'Abstract Principles, Mid-Level Principles, and the Rule of Law', p. 124.
} 
democratic objection, according to which constitutional adjudication is incompatible with the nature of constitutional law, and entails the renouncement of self-government in constitutional democracies. Second, there is the pluralistic objection, according to which comparative adjudication inhibits constitutional pluralism, ${ }^{106}$ as it pursues a uniformity of constitutional doctrines by means of legal transplants and judicial borrowing. ${ }^{107}$ Third, there is the transparency objection, according to which the use of foreign law makes judicial decisions too complex and less intelligible for citizens. ${ }^{108}$ Fourth, there is the cherry-picking objection, according to which the use of foreign law makes the results of adjudication unpredictable and uncertain, being based on the arbitrary selection and use of foreign legal sources.

Let's start with the democratic objection, as raised by Carlos Rosenkrantz against 'borrowings', as well as 'other uses' of foreign law. 'Borrowings' occur when a court takes the decision of a foreign court as authoritative. In his words: 'By "borrowing", I will mean here the decision to use foreign law based, at least in part, upon the authority that foreign law has in its original jurisdiction'. The 'other uses', by contrast, are non-authoritative uses that occur when courts enter a 'universal' dialogue with other courts to find support for their interpretation of constitutional norms. Against all such uses, Rosenkrantz raises a core objection: ${ }^{109}$

\footnotetext{
If we accept the idea that we are supposed to comply with the law only when it is the result of the collective choices of the political entity to which we belong, then we might object to constitutional borrowing simply because borrowing essentially consists of deferring to the collective choices taken by others. The conscious adoption of foreign constitutional law as binding law by a constitutional authority or a judge are both cases in which the most basic themes of our interpersonal lives are decided by people with whom we are not politically related and who are not members of the same political entity. This deferral of the final word to others in constitutional matters is what makes constitutional borrowing incompatible with the principle that coercion can only be justified when it is the direct consequence of a collective choice and, as a consequence thereof, impossible to validate in the context of a constitutional democracy. ${ }^{110}$
}

This objection does not apply, we think, to our account of comparative adjudication qua judicial dialogue. First, the use of

${ }^{106}$ Nico Krisch, Beyond Constitutionalism (Oxford: Oxford University Press, 2010).

${ }^{107}$ On pluralism and comparative law, along these lines, see Pierre Legrand, 'The Same and the Different', in Pierre Legrand and Roderick Munday (eds.), Comparative Legal Studies: Traditions and Transitions (Cambridge: Cambridge University Press, 2003), pp. 240-311.

${ }^{108}$ Carlos F. Rosenkrantz, 'Against Borrowings and Other Nonauthoritative Uses of Foreign Law'.

${ }^{109}$ Rosenkrantz does not distinguish between the judicial use of foreign law and the judicial use of international law, but as we have already stressed, this is a crucial distinction.

${ }^{110}$ Rosenkrantz, 'Against Borrowings and Other Nonauthoritative Uses of Foreign Law', p. 285. 
foreign law that we seek to justify is not a form of 'borrowing', that is, it does not take foreign law to be authoritative or 'binding', but rather persuasive. Second, the kind of engagement with foreign law that we defend amounts to a process of comprehension and refinement of our own constitutional doctrines, rather than abandoning such doctrines or deferring the last word on their meaning and application. Such engagement indicates an intersection among doctrines that also serves as a starting point for further engagement, progressively refining within each comprehensive constitutional doctrine - the connections between mid-level principles and ultimate principles or specific rules.

Second, there is the pluralistic objection. ${ }^{111}$ Against this, we should remark that according to our account, the use of foreign law in constitutional adjudication is justified if framed within a dialogue between courts engaged with each other's arguments, and pursuing a wide reflective equilibrium under criteria of reasonableness as reciprocity. The expected outcome is reasoned convergence on what brings us together, and also reasoned divergence with respect to what makes us legitimately different.

Our engagement model aims at capturing both. It is a dialogical model, framing comparative adjudication as a deliberative process exposing and testing the court's understanding of its own constitutional order against other possible understandings, as well as understandings of other constitutional orders. The ultimate objective is a reasoned comparison, which may end up highlighting similarities as well as differences. ${ }^{12}$ In this way, engagement with foreign law can take a contractive form - when identifying and justifying differences - as well as an integrative form - when identifying and justifying similarities. ${ }^{113}$ Of course, these forms can coexist and highlight convergence in some respects, in spite of divergence in other respects. This does not inhibit, but rather advances constitutional pluralism, by offering new insights into the similarities and differences between a plurality of doctrines.

\footnotetext{
${ }^{111}$ See Krisch, Beyond Constitutionalism.

${ }^{112}$ Sujit Choudhry, The Migration of Constitutional Ideas (Cambridge: Cambridge University Press, 2006), pp. 22-23. On the other hand, judicial dialogue is just one of many ways of pursuing the convergence of constitutional doctrines, including supranational legislation and legal transplants implemented by treaties. See John H. Merryman, 'On the Convergence (and Divergence) of the Civil Law and the Common Law', Stanford Journal of International Law 17 (1981): pp. 357-388.

${ }^{113}$ Rudolf Schlesinger identifies periods of 'contractive' or 'contrastive' comparison, with an emphasis on differences, alternating with periods of what might be called 'integrative' comparison. See Rudolf B. Schlesinger, 'The Past and Future of Comparative Law', American Journal of Comparative Law 43(3) (1995): pp. 477-481.
} 
The third objection focuses on the accessibility, for citizens, of judicial decisions that rely on foreign law. Let us make two remarks against this. First, contemporary law is characterized by many technicalities, and abounds with arguments that are unfamiliar to the general public and make it seem complex. Though highly desirable, simplicity and intelligibility are difficult to realize. What we can try to achieve is clarity with respect to the main reasons that justify legal decisions in the public forum. And here is the second point: a judicial dialogue of the sort we defend aims to achieve such clarity. It relies on wide reflective equilibrium and mid-level principles to expose and progressively shed light on our constitutional doctrines; so it fosters transparency, rather than compromising it.

Finally, let us turn to the cherry-picking objection, in response to which we shall argue that it does not apply to the idea of judicial engagement that we defend.

First, cherry-picking seems to be disproved by data. ${ }^{114}$ As we have already mentioned, the available data show regular patterns of crosscitation among courts, due to the proximity of their legal backgrounds or perceived expertise in a certain field. Besides this factual point, however, there is a second, normative, point concerning the possibility of cherry-picking by courts, when considered as a reason for rejecting this practice. That is, such a possibility is not a plausible ground for desisting from comparative adjudication; rather it is a reason for devising appropriate criteria that may guide judicial selection and use of foreign norms and precedents. In other words, the lack of a solid methodology requires us to elaborate appropriate criteria and guidelines, rather than abandoning the practice. ${ }^{115}$ Our model of judicial engagement goes in this direction, suggesting some possible criteria of comparative adjudication. For instance, we pointed out before that the use of foreign constitutional law and precedents must contribute to understanding our own doctrines. Therefore, a mere list of foreign laws or precedents, or very abstract and general principles of foreign doctrines, is not enough. There

\footnotetext{
${ }^{114}$ Gelter and Siems, 'Citations to Foreign Courts'.

115 Perju, 'Constitutional Transplants, Borrowing, and Migrations'; and 'The Puzzling Parameters of the Foreign Law Debate', Utah Law Review 20 (2007): pp. 167-214. On the epistemology and methodology of comparative law in general, see Mark Van Hoecke and Mark Warrington, 'Legal Cultures, Legal Paradigms and Legal Doctrine: Towards a New Model for Comparative Law', International and Comparative Law Quarterly 47(3) (1998): 495-536; Mark Van Hoecke (ed.), Epistemology and Methodology of Comparative Law (New York: Bloomsbury Publishing, 2004).
} 
must be an attempt to connect foreign law to domestic doctrines, through the formulation of mid-level principles that abstract or generalize the foreign rulings involved, or specify or balance the foundational principles of the foreign doctrines involved. That is to say, mid-level principles must be presented in intelligible terms, and their ties with the different precedents or doctrines at stake must be expounded.

\section{CONCLUSIONS}

We have defended an engagement model of the use of foreign law in constitutional adjudication. According to this model, the use of foreign law is justified if it proceeds by testing and mutually adjusting the principles and rulings of our doctrines against reasonable alternatives, as represented by the principles and rulings of foreign doctrines. By this means, a court aims to establish a wide reflective equilibrium and justify its own interpretation with reasonable arguments, i.e. arguments acceptable from the perspectives defined by other constitutional doctrines, and endorsed by other courts. The point of a judicial engagement of this sort is to work out an overlap between different doctrines, with restrictions on justificatory ascent and descent in legal reasoning. ${ }^{116}$ Such restrictions stem from the kind of deliberative processes that unfold in the judicial forum as part of a liberal forum of public reason, that is, under criteria of reasonableness that constrain the depth and scope of judicial deliberation. Also, our limited competence sometimes leads us to desist from justificatory ascent and descent in our reasoning. ${ }^{117}$

If such restrictions are plausible, we have a reason to embrace and further develop the Rawlsian idea that the exercise of public reason filters out the premises of comprehensive conceptions so as to leave us in the region of an overlapping consensus: a region of mid-level principles that can be shared, notwithstanding legal pluralism and the diversity of comprehensive and reasonable constitutional doctrines.

${ }^{116}$ Dworkin, Justice in Robes; Frances M. Kamm, 'Theory and Analogy in Law', Arizona State Law Journal 29 (1997): pp. 405-426; Sunstein, Legal Reasoning and Political Conflict, pp. 50-53; Sunstein, 'Constitutional Agreements without Constitutional Theories'. From this perspective, as stressed by Kamm (p. 561), even if someone believes that the best justification of our liberal and democratic practices is, for instance, the existence of God, those same practices prevent us from introducing this belief in a justificatory ascent within public discourse.

${ }^{117}$ Sunstein, Legal Reasoning and Political Conflict. 
A judicial engagement of this sort is already partially in place, and if it does not stop, we may reach a consensus on a set of common, shared, mid-level principles:

The real contrast between those who oppose and those who defend the use of foreign law in American legal reasoning is not that jurists in the first group are parochial and the second cosmopolitan. It is rather this contrast between law as will and law as reason. Those who approach the law as a matter of will do not see any reason why expressions of will elsewhere in the world should affect our expressions of will in America. But those who see law as a matter of reason may well be willing to approach it in a scientific spirit that relies not just on our own reasoning but on some rational relation between what we are wrestling with and what others have figured out. ${ }^{118}$

\section{ACKNOWLEDGEMENTS}

We gratefully acknowledge the support of the Spanish government, through the research grants DER2016-80471-C2-1-R (AET) and Ramon y Cajal RYC2012-12175, of the Generalitat of Catalonia, through the research grant 2017 SGR 00823, and of the Alma Mater Studiorum-Università di Bologna, through the CRUI-CARE Agreement. We are grateful to colleagues and friends for comments that greatly improved this work. Thanks in particular to Marcelo Alegre, Samantha Besson, Giorgio Bongiovanni, Damiano Canale, Corrado Caruso, Mathieu Carpentier, Carlos Esposito, Jordi Ferrer, Roberto Gargarella, Matthias Klatt, Mattias Kumm, José Luis Martí, Ezequiel Monti, Philip Pettit, Jahel Queralt, Angeles Rodenas, Carlos Rosenkrantz, Giovanni Sartor, Frederick Schauer, and Anna Stilz. Some of the ideas defended in this article have been presented in Barcelona, Bochum, Buenos Aires, Girona, Graz, Lisbon, Lucerne, and Princeton. We thank the organizers and audiences of those events for their feedback, and for helpful discussions. We are also extremely grateful to two anonymous reviewers and to the editors of Law and Philosophy for comments and suggestions that have greatly improved this work.

\section{FUNDING}

Open access funding provided by Alma Mater Studiorum - Università di Bologna within the CRUI-CARE Agreement.

\footnotetext{
${ }^{118}$ Jeremy Waldron, 'Foreign Law and the Modern Ius Gentium', Harvard Law Review 119(1) (2005): pp. 129-147, on pp. 146-147.
} 


\section{OPEN ACCESS}

This article is licensed under a Creative Commons Attribution 4.0 International License, which permits use, sharing, adaptation, distribution and reproduction in any medium or format, as long as you give appropriate credit to the original author(s) and the source, provide a link to the Creative Commons licence, and indicate if changes were made. The images or other third party material in this article are included in the article's Creative Commons licence, unless indicated otherwise in a credit line to the material. If material is not included in the article's Creative Commons licence and your intended use is not permitted by statutory regulation or exceeds the permitted use, you will need to obtain permission directly from the copyright holder. To view a copy of this licence, visit http:// creativecommons.org/licenses/by/4.0/.

Law Department,

Universitat Pompeu Fabra, Ramon Trias Fargas 25-27, 08005, Barcelona, Spain

E-mail: josejuan.moreso@upf.edu

Department of Legal Studies and CIRSFID-ALMA AI,

Università di Bologna, via Galliera 3, 40125, Bologna, Italy

E-mail:c.valentini@unibo.it

Publisher's Note Springer Nature remains neutral with regard to jurisdictional claims in published maps and institutional affiliations. 